\title{
The Religious Diversity Space Formation Based Private Schools Affiliation in Malang City
}

\author{
Ibnu Mujib \\ History and Sociology Education Study Program, IKIP Budi Utomo Malang \\ Email: ibnumujib@budiutomomalang.ac.id
}

\begin{abstract}
The intolerance that has threatened Indonesia in the last ten years is an important trail to show that the management of diversity in Indonesia is currently having a complex problem. Many parties are starting to question the wisdom of schools as a participatory diversity laboratory. This research emphasizes best practice tolerance education that is integrated into the realm of the learning curriculum in schools, this study more focused on three high school level schools in Malang city based on religion using a comparative descriptive method described by a qualitative critical approach. There is a perspective that is the finding of this research, namely the vision of tolerance and the definition of diversity built-in schools to give birth to patterns of student interaction in daily synergy with other different students. This perspective theoretically can produce five patterns of diversity interaction, namely: first: collegial interaction, second; dialogical experiment, third; intergroup community formation, fourth; participatory ethics, and fifth; transformative action. These five patterns were naturally formed by the vision of tolerance created by the three schools through various activities, both intra and extracurricular, and became patterns of intense participatory interaction in daily activities at school.
\end{abstract}

Keywords: private school affiliates; religious diversity participation; student interaction patterns, vision of tolerance

\section{INTRODUCTION}

The city of Malang, with its various social capitals, can become a miniature portrait of an area that has a fairly high level of diversity in Indonesia. This fact is not only shown by the thousands of immigrants in the city of Malang (Badan Pusat Statistik, 2016) but also the density of students who come and go from year to year to become a new challenge for the diversity of life in this student city. Starting from Eastern Indonesia, Makassar, Ambon, Papua, Kalimantan, to other parts of Central and western Indonesia, Kalimantan, Lombok, Aceh have taken turns feeling the comfort of studying in this educational city. Interestingly, not less than 155,000 incidents of conflict and brawl were recorded between groups of immigrant students in Malang (Parela et al., 2018), which can also be described through profiles in schools in Malang.

Religious diversity education is an urgent need in the midst of intolerance that is threatening Indonesian society (Menchik, 2014). Religion has become an important issue in community conflict in Papua (Ernas, 2016); Disputes between communities in Ambon have also brought about religious diversity (Rumahuru, 2018), burning churches in Aceh (Bustamam- Ahamad, 2016); Ahmadiah attack in Cirebon (Maliki 2010). The attack of the Shia community involving children in Madura, sparking minor conflicts and persecution between ethnic groups and immigrant groups in Malang and several big 
cities in Indonesia (Sanusi \& Muhaemin, 2019). As a result, these various cases have contributed to the dynamics of diversity in schools and the world of education in general.

Not only that, but several social media have also triggered the spread of attitudes of intolerance, religious radicalism, hate speech, the provocation that leads to violence in the name of religion as well as witnesses to Indonesia's diversity today (Hoover, 2011), (Kaplan \& Mazurek, 2018). Not to mention, when the expansion of globalization is getting faster and more massive, social media is now an unstoppable lifestyle choice among students (Hoover, 2011; Stenberg \& Schèabler, 2004). It can be imagined that schools will become the basis of intolerance that thickens in each generation, when there is no room for participation that accommodates common aspirations and concerns. Therefore, this symptom of intolerance confirms that the life of tolerance in Indonesia's diversity is something that is the subject matter in the world of education.

The development of the study of the diversity of society is still at the stage of discourse on pluralism and Multiculturalism on a limited scale. Apart from being discussed as a global product, these issues are still being discussed as a theoretical framework and tend to be as material for academic studies. Meanwhile, the formulation that focuses on applied pluralism and Multiculturalism is still very limited. In previous research on multiculturalism education in schools, the practice is still ongoing at the level of maintaining tolerant attitudes through religious holiday activities by accommodating an unstructured approach (Mujib, 2016). This fact explains that school management Is not yet fully open in providing access to management of diversity in schools in a more structured and measured manner. Therefore, this study tries to offer best practices that are different from the previous findings.

The role of schools is important because schools are strategic institutions in knowledge transfer and attitude formation (Hajisoteriou \& Angelides, 2014). As a strategic institution, schools have a class where they can transform knowledge and also shape student attitudes. Interestingly, the practice of class management, which turns out to be consisting of a variety of certain ethnicities and religions, has encouraged a complete collegial interaction that is not bound by a single and dominant identity (Laksana \& Wood, 2019). In addition to being a place for knowledge transformation, school wisdom also accommodates the various interests of diversity within schools. This includes providing space for an opportunity to initiate the creation of public spaces or spaces for diversity participation in schools (Hefner, 2013).

Based on the above assumptions, two important mutually reinforcing matters are the subject of this paper. Namely, how can the formation of a vision of tolerance and space for diversity participation in the three schools religious based affiliation be able to produce a unique model of diversity interaction?

\section{LITERATURE REVIEW}

The concept of "civic pluralism," which was initiated by Robert Hefner about three main keys in discussing diversity, should be considered. These three terms are built to emphasize the formation of a public space where diversity is recognized and accommodated; agreements and actions for the common good, such as justice, welfare, and equality, are sought. Through this concept, diversity is only meaningful and becomes an effective force if there is a culture of participation that encourages citizens to be involved in discussions on matters of common concern (Hefner, 2009, 2013). 
Robert Hefner, in his work "Civic Pluralism Denied? The New Media and Jihadi Violence in Indonesia (2003) proposed several efforts to manage diversity, including that he revealed three main keys in discussing diversity wrapped in the concept of "civic pluralism,", namely that diversity must contain three key concepts: recognition (recognition). representation (cultural representation) and redistribution (equality in the economic structure of society and public policy), namely emphasizing the formation of public spaces where diversity is recognized and accommodated; agreements and actions for the common good, such as justice, welfare, and equality are sought. Diversity management studied in this study will prove that the three keywords proposed by Hefner above can be shown in the realm of multireligious and multiethnic classrooms in religious and diversity-based schools in Malang.

Through another approach, Bikhu Parekh, a figure who initiated Multiculturalism in his book Rethinking Multiculturalism (Spinner-Halev \& Parekh, 2002), states that the more diverse a society is and the deeper its diversity, the greater cohesion/unity is needed to bind that society. Parekh sees that in the public sphere (such as class), diversity still has to emerge, cannot just be tolerated. According to him, "without having to agree on all values and practices (different groups), a multicultural society must find a way to reshape the public sphere. Following multicultural lines (diversity), in this way, according to Parekh, diversity does not become a division, while unity does not become abstract. The phenomenon of the multiethnic class in this research will often approach Parekh's footsteps, especially in finding a set of methodologies to formulate social cohesion in these multiethnic classes.

In simple terms, the comprehensive doctrine (diversity) can only appear in the public sphere after being translated as the public reason, which functions as a civic language or shared citizenship (Rawls, 2017). Rawls goes on to emphasize the fact that diversity is always there and is permanent and, therefore, must be accepted. Yet he still believes that consensus is needed and that every community has the resources to achieve it. Meanwhile, the idea of public reason emerged as a methodological step to find that consensus. Even though Rawls's liberal view appears to be a counterproductive idea, especially in situations that have the potential for gaps between groups, the requirements for public reasoning have the potential to benefit certain groups and discriminate against other groups (Rawls, 2017).

We can see other facts in the field through the writing: "School-Based Conflict Management" by Rizal Panggabean, 2015. This book explains how conflict management practices are carried out in schools, including how conflict is assessed to practical matters such as how to conduct classroom coaching and peaceful schools, conduct peer mediation, and even deal with bullying that often occurs in the school environment. Conflict management in schools will not only produce a conducive environment for teaching and learning activities but also mature each individual to be able to accept differences as gifts and learning, not problems or sources of conflict. This book is also the Sukma Bangsa school's direct response to the conditions of violence in Aceh, especially in the post-earthquake, tsunami, and conflict education environment. The explanation of this book is also strengthened in his writing in the journal of education (Panggabean, 2017). These ideas illustrate how the management of multireligion and ethnic classrooms as public spaces of diversity can take place in schools or in classrooms. 


\section{RESEARCH METHODS}

This research has captured closely the best practice experiences carried out in three private schools in Malang in an effort to build religious diversity education, namely Senior High School Catholic Kosayu Malang, Senior High School Islam Sabilillah Malang, and Senior High School Selamat Pagi Indonesia in Batu city. These three schools were selected as a sample of how the diversity of students at the school level can be formulated into an important part in formulating public spaces for religious diversity in schools. For this reason, this research was conducted using a comparative qualitative descriptive method, which was then explained using a qualitative critical approach in order to find the deepest gaps in a condition that actually occurred in the three schools.

\section{RESULTS AND DISCUSSION}

\section{The Vision of Tolerance and Participation of Diversity In Three Schools}

The explanation of the vision of tolerance for the three high schools here will be described descriptively through the school's vision and mission as well as other findings obtained from interviews with several school stakeholders, including school principals, teachers, and students. Through the data we obtained in the field, it also illustrates the interaction model created by the school, of course, based on the existing vision and mission of the school. Following is a brief overview of the vision of tolerance and the definition of diversity we will adequately review one by one

The definitive Kosayu Catholic High School has a goal that leads to the development of the character of the nation's children, which is reflected in the context of activities or the touch of the Indonesian and religious-based curriculum context, where the idea leads to the realization of the vision and mission of the school to be communicative and measurable (guidebook technical Senior High School Kosayu, 2017). Not only that, it improves the quality of character for students, fosters attitudes and values of tolerance so that they are able to appreciate the diversity around them. One of the PPKN teachers in this school, Mrs. Kristin shows that

"the vision of the school as an agent of tolerant is an urgent matter to do in all schools in Indonesia" (Interview, September 2018.)

In addition, schools also increase student knowledge and skills in accordance with the demands of the developed curriculum, as well as intensify the role of parents in mentoring activities to develop student personalities so That they care for the surrounding community, including raising awareness of teachers and parents and the community that education requires exemplary (technical guide, 2017). No less important, namely increasing the professionalism and competence of teachers, increasing awareness of clean, healthy, orderly, safe, neat, and modest living. Not only that, the vision and mission are also strengthened by improving facilities and infrastructure that support the learning process, as well as developing human relations among school members. These are all a series of school goals that were stated definitively in developing character students (vision and mission of Senior High School K Kosayu 2017).

Meanwhile, the different school is Senior High School Islam Sabilillah. The vision of tolerance developed by SENIOR HIGH SCHOOL Sabilillah places more emphasis on strengthening developing attitudes, knowledge, and skills and implementing them in various situations in schools and the surrounding community so that this vision creates 
a character as the ideals of this institution. Professor Ibrahim Bafadal as the director of LPI Sabilillah, said that:

"the institution intensively continues to provide a very wide space and time to develop various attitudes, knowledge, and skills, especially in building student character both in schools, families and the environment, including developing tolerance in build student social interaction at school and in the community, (interview September 2018).

Table 1. Distribution based religious diversity in 3 school

\begin{tabular}{|l|c|c|c|c|c|c|}
\hline \multicolumn{1}{|c|}{ Name of School } & studen quantity & Muslim & Christianity & chatolic & Hinduism & Budhis \\
\hline SMA Kosayu & 540 & 53 & 73 & 351 & 7 & 39 \\
\hline SMA I Sabilillah & 605 & 605 & 0 & 0 & 0 & 0 \\
\hline SMA Selamat Pagi & 375 & 215 & 20 & 112 & 15 & 13 \\
\hline
\end{tabular}

Source: School document 2019

Although, according to the table 1, states that Senior High School Islam Sabililah does not fulfill the quorum in diversity based on religion, but the vision of tolerance that is built in the school is quite high, especially in coloring the multicultural repertoire and education of the tolerant character of its students.

It is somewhat different than Senior High School Selamat Pagi Indonesia in Batu City has a unique vision of tolerance. In addition to the very diverse students, the targets and orientation of the school institutions indeed focus on strengthening human resources or students from entrepreneurial life, so that the diversity bases at the level of views or institutional ideology are also relatively in line with the life of the mainstream of Indonesian society in general, namely using madhab. Diversity, not a particular religious group. In addition to the fact That because the students come from various regions and are supported by the religious backgrounds of students who are also very varied, both institutionally and by their students, they take a moderate position in religious attitudes. Said the owner and manager of this school.

Therefore, they define a learning revolution to create a character for students in their schools. Character is the behavior of an individual's inner nature that affects all individual thoughts, behavior, manners, and character. Usually, characters have a close relationship with what is called morals (manners). That way, a good character will give birth to good morals for the individual. The character-building process can be seen through habituation activities at school and outside of school. As in Senior High School Sabilillah itself, habituation is always applied to love Allah and His Messenger, as well as parents and teachers, themselves, among others, the existing diversity and also the natural surroundings. This includes love for the excellence of science and technology, as well as love for the nation and state (technical guidebook, Senior High School Sabilillah, 2018).

One of the extracurricular activity practices, as a private school in Malang City, where most of the students have Chinese ethnic background, every year, it always commemorates special Chinese New Year moments with activities that can attract people's attention. One example of what they do is wearing Qi Bao clothes, with shades of bright red. At least if they don't have these clothes, they combine their clothes with matching the Chinese New Year theme. That was conveyed by informant Eka (12):

"moments of diversity that we have like this are jewelry that we will wear and will always care, for now, tomorrow and in the future" (interview March 11 2018). 
Moments like this are said to have started with the activity of decorating the class with Chinese nuances. For example, with angpau decorative forms, Chinese New Year theme hangers, monkey pictures, ribbons, colorful paper, and a complete cherry tree appear to have enlivened the Imlak activities at that time, especially in classes. Nuances like this closely characterize this school, until the climax of the event, which is followed by a meal together with class members and followed by a blessing in the classes by Father Sukamto. And there are many other character-building activities, including tolerance practices that are packaged in the form of extracurricular activities.

Table 2. Distribution based ethnic diversity in 3 school

\begin{tabular}{|c|c|c|c|c|c|}
\hline school name & student quantity & Java & China & Batak & Sunda \\
\hline SMA Kosayu & 540 & 220 & 302 & 11 & 5 \\
\hline SMA I Sabilillah & 605 & 420 & 102 & 8 & 75 \\
\hline SMA Selamat Pagi & 375 & 120 & 109 & 103 & 43 \\
\hline
\end{tabular}

According to table 2, Senior High School Kosayu tends to have a fairly high level of ethnic diversity compared to the other two schools, although Senior High School Selamat Pagi Indonesia also has almost equal levels of majority ethnic diversity. Therefore, it is not surprising that extra activities that lead to providing more space for ethnic Chinese take place at this school.

The extracurricular activities in these three schools are carried out as special laboratories, especially in their efforts to manage diversity in schools. In this practice, extracurricular activities include various types of supporting activities, such as the explanation of Pak Lukman (51), a PKN teacher from the Islamic school of Sabilillah, stated

"for student character-building activities focused more on extracurricular activities, some activities such as welcoming religious holidays, activities scouts with an emphasis on disciplinary content. " However, continued Pak Lukman, "It is different from deepening insight through material related to diversity which is embedded in several special subjects, such as religion, social studies, language, and cultural arts, while for practice it is in extracurricular activities and religious holidays." So that what can be observed from their diversity practices are attitudes that are reflected from the habits that are carried out in school. (Lukman, June 2018)

Apart from extracurricular activities and taking advantage of religious holidays, each school also includes messages of diversity in the learning curriculum that focuses on diversity issues in schools. They use certain subjects such as religion, social studies, language, and cultural arts to facilitate the development of attitudes, knowledge, and experiences of diversity in schools (e.learning Senior High School Sabilillah, 2020).

\section{Model of Religious Diversity Participation In Schools}

The interaction between students that was built in these three schools shows a unique and very diverse fact. During the observation and interview period, several patterns of interaction were found in the school, including 
Figure 1. Circle of diversity participation in schools

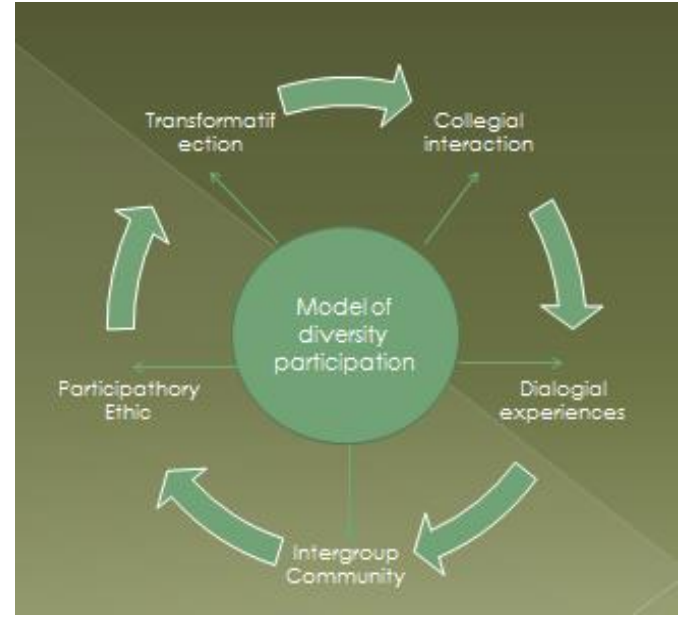

The five models of diversity participation interaction shown in the above participation model circle have taken place in the three schools we selected with an explanation of each model as described below.

1. Model of Collegial interactions

Friendship interactions, or we call Collegiate interaction is a form of student interaction built on the basis of ordinary friendships without being adhered to by elements of religious or ethnic differences. As told by Yolan (43 years), a teacher at Senior High School Kosayu said that

"the friendship between various students in the classes includes a friendship with the background of taking the same class, namely class $C$. Then they also take different fields of study. the same, so their sincere friendship does not carry the frills of religion or ethnicity. (FGD May 2018).

Figure 2. collegial interaction

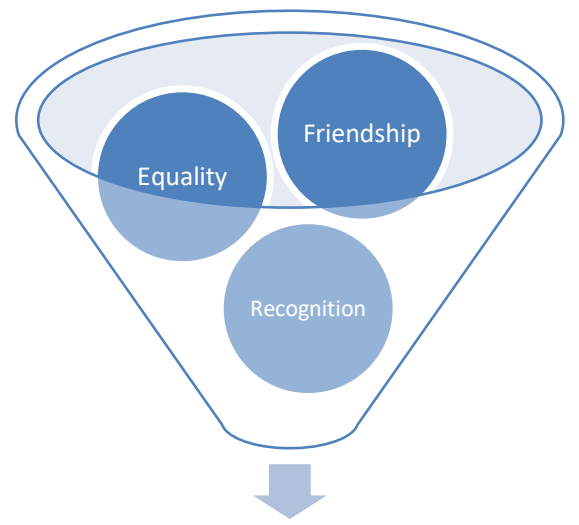

Slightly different from Pak Anton, a PKN or Pancasila teacher in Kosayu, telling about his student whose name Indah, is grade 3 Senior High School from Java. He also described that:

"Our friendship is very natural. Apart from what Yolan did, we also collaborated in making school assignments; it's impossible when I work together to finish homework from school I have to limit myself because my friends come from different religious backgrounds, it's strange for me (FGD May 2018). 
The two interview quotes above explain the insignificance of attaching elements of belief or ethnicity to friendships between friends in class and outside of class, the most important is the word friendship, recognition between friends, friends to acknowledge each other, and equality among friends, there is no difference in economic class or skin color. They are human they are equal as human beings. Therefore all differences do not become a barrier to their friendship. This relationship is known as collegial interaction.

2. Model of Dialogical Experience

The interaction model, which they call dialogical experiment, is a dialogical experience or communication, or interaction experience that involves language and body speech between students. According to one of the Sabilillah Senior High School managers, this interaction pattern shows a dialogue experience recorded by students during interacting and communicating both verbally and non-verbally, which then becomes an accumulation of actions in response to the diversity that exists in the school. Dani (47th), the head of the academic department and also a PPKN or Pancasila teacher at Selamat Pagi Indonesia, said that:

"understanding language is very important in communication patterns in this school, so students are required to be able to adapt to dialogical experiential patterns" (FGD May 2018).

This statement emphasizes that communication experience is an important source in managing diversity, including difficulties in understanding the language of colleagues who happen to be of different ethnicities as well as part of new problems that become obstacles for students in carrying out the vision of diversity in schools.

Figure 3. Dialogical experiences.

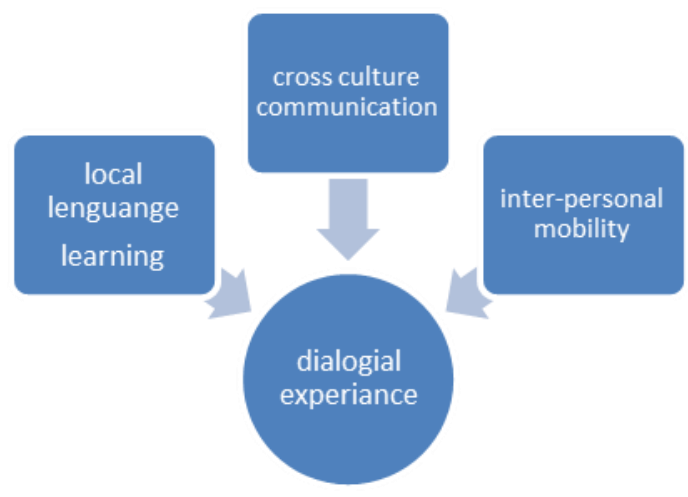

The experience of communicating with friends of different ethnicities and religions at school requires patience for other students. A somewhat different experience was found; Asgar, a second-grade student of Senior High School Sabilillah from Malaysia, said that

"I can't speak Indonesian well, there are friends who are patient in teaching Indonesian well, but some are indifferent, and there are those who I don't just talk to every time I approach them. He left me, but I understand for sure he doesn't really understand my conversation" (FGD May 2018). 
There are at least three indicators for the dialogical experience model, namely first, that the dialogue they carry out is involved in cross-cultural communication, the dialogue process they take brings cross-cultural aspects, both ethical experience or knowledge experience, second, dialogue that is They do reach the inter-personal mobility aspect, the solidarity of personal mobility that they build also produces experiences for shared mobility. Furthermore, their third dialogical experience is learning from each other in their respective local Languages. This experience will be more meaningful if the process of learning local languages is then strengthened by understanding each other's identities, so that diversity of identities can be learned through the local language system.

3. Model of Intergroup Community Formation

The intergroup community formation model is a pattern of interaction that is built as long as they exist in diverse communities in their respective classes and schools. They experience fundamental differences in the state of their social experiences before joining and after joining communities that are diverse both religiously and ethnically. This kind of social situation can be imagined when awareness of the formation of interreligious and inter-ethnic communities slowly but surely fosters an inner attitude about a primordial relationship that involves empathy, mutual solidarity, and sincere friendship.

Angga, one of the Selamat Pagi Indonesia High School students (Muslim) in an interview stated

"since I went to high school, I met to recognize and feel about the reality of living side by side with friends of different religions and ethnicities, some of them from Catholic, Protestant, Buddhist. in fact, many of them are ethnic Chinese. I am very lucky to be in their class. If Muslim friends are used to it, concluded grade 2 Senior High School Selamat Pagi Indonesia. (FGD May 2018).

In another cluster, a statement from Sinta (18 years), one of grade 2 students, also appeared.

"The change in attitude that I have experienced since I entered high school Selamat Pagi Indonesia is that I feel friends as they are and are comfortable, regardless of their religion or ethnicity, but it was different before I went to school here, I used to have a bit of hatred with those who have. religion is different from mine, and that too because of friends". (FGD May 2018)

Figure 4. Dialogical experiences.

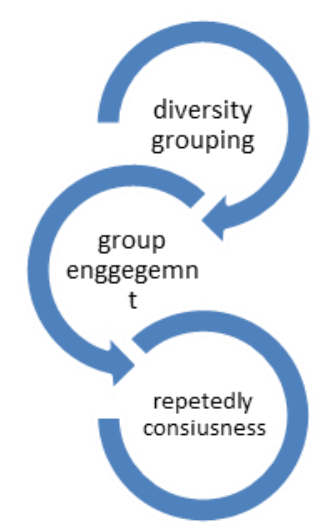


The two views above show experience of interacting as well as side by side with quite a variety of friends in the class, especially at Selamat Pagi Indonesia High School, which happens to be where they undergo the teaching and learning process. And the most important thing is that what is called an intergroup community construction is a bond of friendship built on the basis of the formation of communities across religious and ethnic groups.

There are several indicators of action on the basis of the interactions they create during class or school. Among them is the diversity grouping, which means that the class is deliberately designed to be a group containing multi-religious or ethnic groups; group engagement means that each group plays itself as a partner who continues to be involved in various activities or programs. C class, until finally there repeatedly consciousness (repeated awareness) what they do by engaging in-class activities intensely has formed intergroup based community construction. These three indicators are translated into pillars that shape it into an intergroup based community construction.

\section{Model of Participatory Ethics}

At this point, the school is also building what is known as participatory ethics. Participatory ethics illustrates the importance of involving students in ethical issues of diversity in schools. In some of the schools studied, there are certain ethics that underlie the interaction process that has been adapted sustainably in schools. Pak Bambang's explanation, one of the teachers at Senior High School Selamat Pagi, said that:

"schools also build ethical involvement for students to respond to diversity in schools, for example, the ethics that developed in Senior High School Selamat Pagi are Javanese ethics, so for students who have other ethnicities it is hoped they can adjust and adapt the big ethics that apply in schools. " (FGD May 2018).

The text excerpt in the FGD above also supports the development of cultural experiences between students who have different ethical backgrounds, beliefs, and ethnicities. Rudi, a grade 3 student at catholic Senior High School Kosayu told that "even though I am a follower of Islam I often adjust the ethics of my Chinese friends, because the majority of students here have chains backgrounds, as long as it doesn't conflict with the religion I profess, even though they actually don't force it. I have to follow their culture or religious ethics. (FGD May 2018). This story defines a student's adaptation process to other students with different ethical backgrounds, cultures, religions and ethnicity.

Figure 5. The participatory ethic

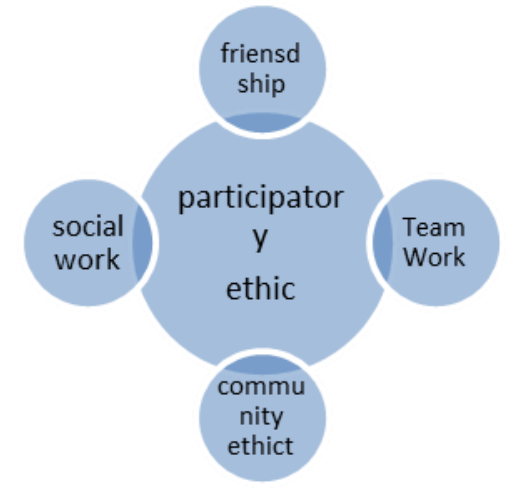


The four indicators in understanding participatory ethics above can be found in the ethical construction model they show daily. First, friendship, they call friendship or friendship. Starting from this friendship, they will always hold the principles of charity, including friendship ethics. Like commitment, empathy, caring, not choosing friends, let alone differences. The friendship aspect is key in appreciating the differences between them. Second, after friends, they must be willing to work with a team; the friendship they build is continuously supported by teamwork or solidity into, both the team in doing group tasks and the team engaging in work. Friend. Third, they also said that efforts to involve themselves in their community must also be supported by existing community ethics, so that the togetherness they create is always strengthened because they maintain community ethics together. Fourth, there is a social work pattern that they build to strengthen the role of friendship. This is another form of solidity into out. In addition to building solidity within them, they also develop solidity outside. From this pattern hereinafter referred to as transformative actions.

\section{Models of transformative actions}

The fifth pattern they call Transformative actions or transformative actions, this model describes a form of interaction that is built on the basis of transformative actions or collaborative actions across religious, ethnic, or racial diversity in real terms carried out between students of different ethnic backgrounds and religion. The school describes this model as the real interaction of different students doing social service cooperation, planting trees, helping communities with clean water crises, or other collaborations that involve students at school. Apart from responding to diversity, this school still maintains it as a form of an effort to build student character so that they are accustomed to collaborating with others, both within a group and outside the group.

Faizal, a grade 3 student of Senior High School (boarding school), Sabilillah, told of his involvement in the social work carried out by the school, such as the work of planting 1000 pine trees in the Wagir area, Malang regency, April 4, 2016. (Also Febri, grade 3 student Sabilillah, told of his involvement in helping social services communities affected by the clean water crisis in March last year (2016). Each was conveyed in the FGD in May 2018).

The social service carried out by Sabilillah Malang students is also part of social habituation that should be reproduced continuously to manage social appropriateness, where the patterns of habituation that are cared for through this social service will present what is called transitive critical awareness for students or students. , especially for school institutions that have a big agenda for the implementation of tolerance education in schools.

The excerpt discussion above also supports the development of cultural experiences between students with different ethical backgrounds, beliefs, and ethnicity. Rudi, a grade 3 student at catholic Senior High School Kosayu, said that

"even though I am a follower of the Islamic religion I often adjust the ethics of Chinese friends, because the majority of students here have chains backgrounds, as long as it doesn't conflict with the religion I profess, even though they actually don't force it. I have to follow their culture or religious ethics. (FGD May 2018). 
This story defines a student's adaptation process to other students with different ethical backgrounds, cultures, religions and ethnicity.

Figure 6. transformative action

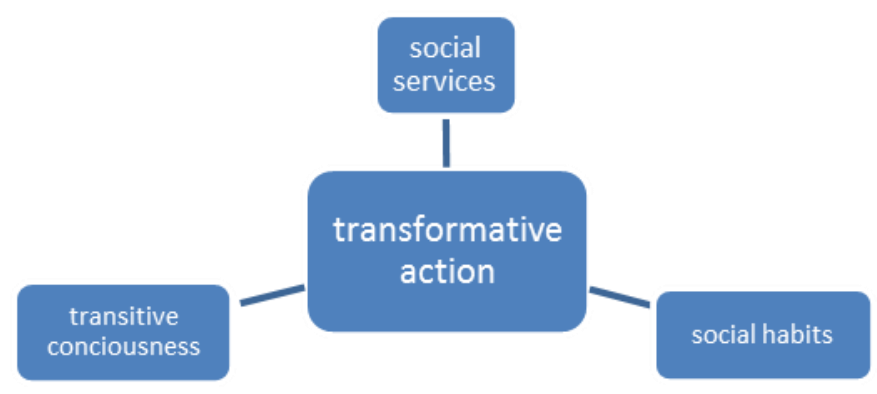

There are at least three points of action or actions that can rely on a transformative action pattern, which is a pattern that transforms from experiences of diversity both in the classroom and at school to experiences of concrete actions, such as social service, habituation to character building and soul. social activities of other students, and cultivating transitive awareness, which is a spontaneous action recorded from the memories of the constructs

They constructed during their joining experiences of various religions and cultures. Not only finished here, but the practices of tolerant character habituation which are shown in the school's vision at the same time through the interactions created are also then strengthened through approaches and enrichment of knowledge that are wrapped in the learning process, namely through the integrated tolerance education curriculum. This section will be discussed in other researches.

\section{CONCLUSION}

Schools have very strategic social capital, not only about diversity itself; in schools, they have been taught to recognize (recognition) of their rights as fellow students on behalf of students or learners, not in the name of religion or ethnicity. In schools also teaches aspects of representation (representation) of existing cultures, religions, and races. Not only that, but in schools, students also understand the importance (redistribution) of equality in the economic structure of society and public policies, namely emphasizing the formation of public spaces where diversity is recognized and accommodated; agreements in carrying out actions for the common good, such as aspects of justice, welfare and equality will always be considered. Through the theory popularized by Robert Hefner here that diversity is only meaningful and becomes an effective force if there is a culture of participation that encourages students to be involved in discussions about matters of common concern.

The formation of an interactive participation model in schools did not suddenly appear because of the design of the school or school institution elites, but this model emerged naturally when the spaces for diversity participation were opened and created in a conventionally by the three schools. Not only did Senior High School Sabilillah have their roots in the formation of the tolerant character of their students, but Senior High School Kosayu emphasized more through the basis of religious and ethnic 
Multiculturalism created in schools. Meanwhile, the diversity participation space created at Senior High School Selamat Pagi Indonesia is more developed due to the habit of interacting with friends who have a strong diversity background.

The experience of managing diversity in schools is not an easy thing to do; it must get the support of many parties. It requires concepts or ideas that are operable and, of course, grounded with relevant practices and can be reached by activities at school. Because schools have their own wisdom in describing the management of diversity, it becomes a vision of tolerance and the creation of spaces for diverse participation in schools. These three high schools based on religion and diversity in Malang are able to translate the context of diversity management into a school participation space.

Through the comparative descriptive method with a social anthropological approach, this study was able to narrate the aspects of managing diversity comprehensively through the participatory public space instruments they created, starting from the aspects of school management, open classroom management, the integrated tolerance education curriculum, which is a vice curriculum for anti-intolerance and radicalism, to the learning process that involves teachers with cross-cultural paradigms in certain fields of study in schools. This study is very concerned with the issue of school profile, readiness, and support from the entire school academic community.

\section{REFERENCES}

Badan Pusat Statistik. (2016). Kota Malang Dalam Angka.

Hajisoteriou, C., \& Angelides, P. (2014). Facing the Challenge: School Leadership in Intercultural Schools. Educational Management Administration and Leadership, 65-82. 10.1177/1741143213502194

Hefner, R. W. (2009). Islamic Schools, Social Movements, and Democracy in Indonesia. In Making Modern Muslims (pp. 55-105). 10.21313/hawaii/9780824832803.003.0002

Hefner, R. W. (2013). The Study Of Religious Freedom In Indonesia. Review of Faith and International Affairs, 11(2). https://doi.org/10.1080/15570274.2013.808038

Hoover, S. M. (2011). Media and the Imagination of Religion in Contemporary Global Culture. European Journal of Cultural Studies, 14(6), 610-625. https://doi.org/10.1177/1367549411419980

Kaplan, A., \& Mazurek, G. (2018). Social Media in Handbook of Media Management and Economics (Second Edi). Routledge.

Laksana, B. K. C., \& Wood, B. E. (2019). Navigating Religious Diversity: Exploring Young People's Lived Religious Citizenship in Indonesia. Journal of Youth Studies, 22(5), $1-17.10 .1080 / 13676261.2018 .1545998$

Menchik, J. (2014). Productive Intolerance: Godly Nationalism in Indonesia. Comparative Studies in Society and History, 56(3), 591-621. https://doi.org/10.1017/S0010417514000267

Mujib, I. (2016). Multicultural Education Practices at religiously-based Schools in Malang. Al-Albab IAIN Pontianak, 5(2). https://doi.org/10.24260/alalbab.v5i2.425

Panggabean, R. (2017). Institusionalisasi Manajmen Konflik Berbasis Sekolah. Sukma: Jurnal Pendidikan, 1(1), 197-218. 10.32533/01107

Parela, K. A., Saffanah, W. M., \& Anwar, K. (2018). Konflik Mahasiswa Timur Di Kota Malang (Studi Kasus Pada Mahasiswa Timur Di Kota Malang). Jurnal Pemikiran Dan Penelitian Sosiologi. https://doi.org/10.24198/jsg.v3i1.19278

Rawls, J. (2017). Idea of Public Reason Revisited in Constitutionalism and Democracy. In The University of Chicago Law Review (Vol. 64, Issue 3).

Rumahuru, Y. Z. (2018). Mengembangkan Pendidikan Agama Inklusif Sebagai Solusi 
Pengelolaan Keragaman Di Indonesia. 10.47131/jtb.v1i1.13

Sanusi, I., \& Muhaemin, E. (2019). Intoleransi Keagamaan Dalam Framing Surat Kabar Kompas. Communicatus: Jurnal IImu Komunikasi, 3(1). 10.15575/cjik.v3i1.5034

Spinner-Halev, J., \& Parekh, B. (2002). Rethinking Multiculturalism: Cultural Diversity and Political Theory. Contemporary Sociology, 31(2). 10.2307/3089515

Stenberg, L., \& Schèabler, B. (2004). Globalization and the Muslim World: Culture, Religion, and Modernity. Modern Intellectual and Political History of the Middle East. 